\title{
Association of Knee Muscle Strength with Lower Extremity Dysfunction in Patients with Osteoarthritis: a Comparison with Rheumatoid Arthritis Patients and Healthy Controls
}

\author{
Osteoartritli Hastalarda Diz Kas Gücünün Alt Ekstremite Disfonksiyonu ile İlişkisi: \\ Bu İlişkinin Romatoid Artritli Hastalar ve Sağlıklı Kontrollerle Karşılaştırılması
}

\author{
Yasemin ULUS, Murat SAVLIK, Yeşim Akyol, Berna TANDER, Ayhan BİLGİCİ, Ömer KURU
}

Department of Physical Medicine and Rehabilitation, Medical Faculty of Ondokuz Mayıs University, Samsun, Turkey

\begin{abstract}
Objectives: This study aims to evaluate the relationship between knee muscle strength and lower limb dysfunction in patients with osteoarthritis (OA) in the lower limbs.

Patients and methods: $A$ total of 126 subjects including 42 with $O A$ in the lower limbs, 42 with rheumatoid arthritis (RA) and 42 healthy controls (mean age $52.65 \pm 7.17$ years; range 40 to 71 years) were enrolled. The lower limb pain of the patients was evaluated using the visual analog scale (VAS). All participants underwent an isokinetic knee muscle strength test, a six-minute walking test (6MWT), and the Rheumatoid and Arthritis Outcome Scale (RAOS). The disease activity scores involving 28 joints (DAS 28) of RA patients and the Kellgren-Lawrence scores of OA patients were recorded.
\end{abstract}

Results: The pain intensity was similar in the OA and RA patients. There was no statistically significant difference among the three groups in terms of the 6MWT times. All of the RAOS subscales were significantly lower in the $O A$ and RA patients compared to the control group $(p<0.001)$, however, there was no statistically significant difference between the two patient groups. No significant difference in the isokinetic peak-torque (PT) ratio was observed among the groups. In the OA and RA patients, the VAS score was not correlated with none of the PTs, while the 6MWD showed a significant association with all PTs. Correlation and regression analyses revealed relationship between the PT measurements and a few RAOS subscales. There was no significant relationship between the PTs and DAS 28 in RA patients. No significant effects the radiological grade with regard to the 6MWD, RAOS subscales, and PTs were found in OA patients.

Conclusion: Our study results demonstrated that a higher number of $\mathrm{OA}$ and RA patients with lower limb involvement have lower-limb dysfunction, compared to those without any rheumatological disorder. We conclude that the burden of the disease may be similar in OA and RA patients with lower limb involvement, which may have an adverse effect on the functional capacity of the patients.

Key words: Lower limb function; muscle strength; osteoarthritis; rheumatoid arthritis.
Amaç: Bu çalışmada alt ekstremite tutulumu olan osteoartrit (OA) hastalarında diz kas gücü ile alt ekstremite disfonksiyonu arasındaki ilişki değerlendirildi.

Hastalar ve yöntemler: Çalışmaya alt ekstremite tutulumu olan $42 \mathrm{OA}$ ve $42 \mathrm{RA}$ hastası ile 42 sağlıklı kontrol olmak üzere toplam 126 katılımcı (ort. yaş 52.65 \pm 7.17 yıl; dağılım 40-71 yıl) alındı. Hastaların alt ekstremite ağrısı görsel analog ölçeği (GAÖ) ile değerlendirildi. Tüm katılımcılara izokinetik diz kas gücü testi, altı dakika yürüme testi (6DYT) ve Romatizma ve Artrit Sonuç Ölçeği (RAOS) uygulandı. Romatoid artrit hastalarında 28 Eklemde Hastalık Aktivite Skoru (DAS 28) ve OA hastalarında KellgrenLawrence skoru kaydedildi.

Bulgular: Ağrı şiddeti $O A$ ve RA hastalarında benzerdi. Her üç grup arasında 6DYT zamanları açısından anlamlı bir istatistiksel fark yoktu. Tüm RAOS alt parametreleri, kontrol grubuna kıyasla, OA ve RA hastalarında anlamlı olarak düşüktü $(p<0.001)$; fakat hasta grupları arasında istatistiksel olarak anlamlı bir fark yoktu. Gruplar arasında izokinetik piktork (PT) oranı açısından istatistiksel olarak anlamlı bir fark gözlenmedi. Osteoartrit ve RA hastalarında 6DYT, tüm PT'ler ile pozitif ilişkiliyken, GAÖ ağrı skoru PT'lerden hiçbiri ile ilişkili değildi. Korelasyon ve regresyon analizleri ile PT ölçümleri ve RAOS alt parametrelerinin çok azı arasında ilişki saptandı. Romatoid artrit hastalarında PT'ler ile DAS 28 arasında anlamlı ilişki saptanmadı. Osteoartrit hastalarında radyolojik evrenin 6DYT, RAOS alt parametreleri ve PT'ler üzerine anlamlı etkisi saptanmadı.

Sonuç: Çalışma sonuçlarımız alt ekstremite tutulumu olan $O A$ ve RA hastalarının, romatolojik hastalığı olmayan kişilere kıyasla, daha fazla alt ekstremite disfonksiyonuna sahip olduğunu göstermektedir. Alt ekstremite tutulumu olan $O A$ ve RA hastalarında hastalığın yükünün benzer olabileceği ve bu hastalıkların hastaların fonksiyonel kapasitesi üzerinde olumsuz bir etkiye sahip olabileceği sonucuna varılabilir.

Anahtar sözcükler: Alt ekstremite fonksiyonu; kas gücü; osteoartrit; romatiod artrit.

Received: June 29, 2012 Accepted: August 13, 2012

Correspondence: Yasemin Ulus, M.D. Ondokuz Mayıs Üniversitesi Tıp Fakültesi, Fiziksel Tıp ve Rehabilitasyon Anabilim Dalı, 55139 Kurupelit, Samsun, Turkey. Tel: +90 362 - 3121919 e-mail: yaseminulus@gmail.com

(C2013 Turkish League Against Rheumatism. All rights reserved. 
Osteoarthritis (OA) is the most common articular disease and is associated with pain, joint stiffness, and a progressive loss of function. Although it can involve any joint in the body, the hands and feet, hips, and knees are most often affected. ${ }^{[1]}$ Rheumatoid arthritis (RA) is a chronic, generally progressive autoimmune disease characterized by systemic impairment and symmetrical peripheral polyarthritis that leads to deformities and destruction of the joints. ${ }^{[2]}$ Both OA and RA affect the musculoskeletal system and influence a person's ability to perform the functional activities and tasks that are expected of an independent adult. ${ }^{[3]}$ They may cause considerable pain, limited physical functioning, and disability. ${ }^{[4,5]}$ Muscle weakness, restricted joint range of motion (ROM), and reduced physical function are common signs in patients with OA or RA. ${ }^{[6]}$

Muscle strength is one of the determinants of functional status together with flexibility, ROM, physical fitness, and body composition. ${ }^{[7]}$ An interaction between muscle strength and functional limitations has been previously shown, and it has been suggested that a threshold level of strength may be required to perform basic activities of daily living (ADL). ${ }^{[7]}$ Past studies have reported that patients with OA or RA have reduced muscle strength compared with healthy subjects, ${ }^{[8-10]}$ and other studies have been published on the relationship between muscle strength and disability or quality of life (QoL) in OA or RA patients. However, comparative research on muscle strength and disability in these patients is limited in the literature. ${ }^{[4,11,12]}$ In fact, to our knowledge, there have been no studies that have assessed the relationship between muscle strength and functional status of lower limbs in OA and RA patients. Therefore, in this study, we aimed to evaluate the association of knee muscle strength with lower extremity dysfunction in OA and RA patients and compare the findings with those of healthy subjects.

\section{PATIENTS AND METHODS}

The study was conducted at the Department of Physical Medicine and Rehabilitation of the Medical Faculty of Ondokuz Mayis University. The local ethics committee approved the study protocol, and all participants gave their written informed consent. Forty-two patients with lower limb OA and 42 patients with lower limb RA who had been diagnosed based on the criteria of the American College of Rheumatology (ACR) ${ }^{[13-15]}$ were enrolled in the study. In addition, 42 gender- and age-matched healthy controls with no clinical signs of OA or RA and no reports of OA or RA as a concomitant disease were also included. All of the study participants ranged between the ages of 40 and 71 (mean age 52.65 7.17). Subjects were excluded if they were bedridden, had Parkinson's disease, stroke, multiple sclerosis, epilepsy, or a history of cardiac syncope. In addition, those with cognitive or psychiatric disorders ${ }^{[4]}$ and those that had undergone lower limb surgery ${ }^{[5]}$ or intraarticular viscosupplementation were not included as well as those who had received a corticosteroid injection within the last six months. Finally, RA patients on biologic drugs and those with joint complaints due to osteoarthritic changes were also excluded from the study.

Data was collected related to age, gender, body mass index (BMI), working status, educational level, medical comorbidities, current medications, and disease duration. Pain in the lower limbs was assessed by a visual analog scale (VAS) in which a score of 0 indicated no pain and a score of 10 represented very severe pain.

The six-minute walking test (6MWD) was used to objectively assess functional performance and endurance, ${ }^{[16]}$ and the participants completed this using a 42.6 meter walkway. They were given the same standard verbal instructions before each test and instructed to walk their maximum distance in a six-minute period. The total distance covered in meters during this time was then used as the score for each session.

The functional capacity of the lower extremities of the participants was evaluated using the Rheumatoid and Arthritis Outcome Score (RAOS), a selfadministered instrument that consists of 42 items that assess five separate patient-relevant dimensions: pain (nine items); other symptoms like stiffness, swelling, and range of motion (ROM) (seven items); ADL (17 items); sport and recreational activities (Sport/Rec) (five items); and lower limb-related QoL (four items). Answers to the questions on the RAOS were recorded using five Likert boxes (no, mild, moderate, severe, extreme), and all items received a score of between zero and four. Afterwards, each of the five subscale scores were totaled to get the sum of the included items. This outcome instrument for the assessment of multidisciplinary care was found to be reliable, valid, and responsive, ${ }^{[17]}$ and the Turkish version of the RAOS was also preciously determined to be reliable and valid. ${ }^{[18]}$ 


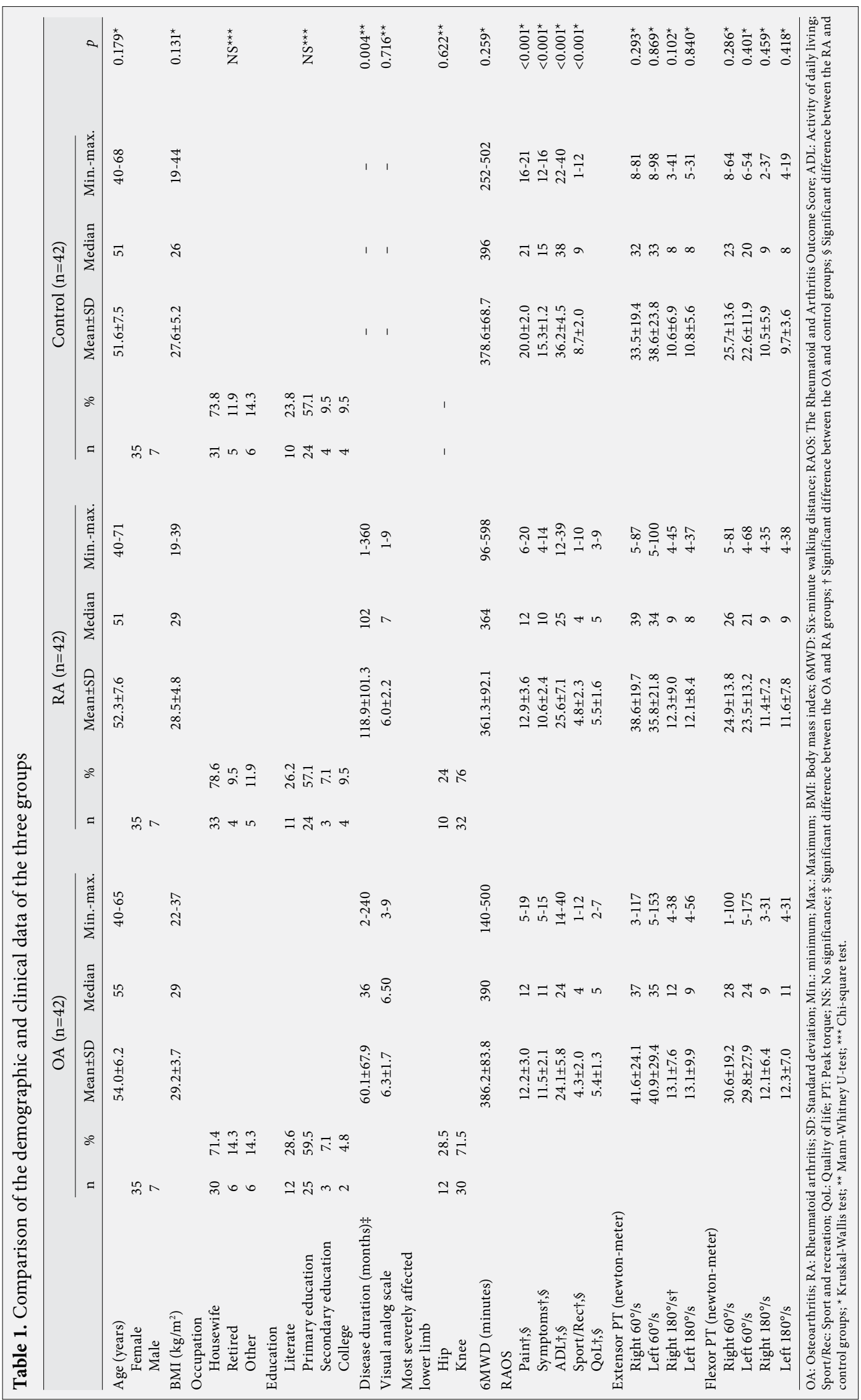


Computerized isokinetic assessments of the knee muscles were performed bilaterally on a Cybex isokinetic dynamometer (Cybex HUMAC NORM Testing \& Rehabilitation System, Computer Sports Medicine, Inc., Stoughton, MA, USA), and the same examiner performed the measurements using the same test protocols. After explanations were given, the subjects were performed the procedure by doing three submaximal repetitions at each speed using the protocol of bilateral concentric/concentric knee flexion and extension at velocities of $60 \% \mathrm{sec}(10$ repetitions) and $180 \% \mathrm{sec}$ (10 repetitions). ${ }^{[19]}$ The movement range was set in the pain-free $90^{\circ}$ of knee flexion in neutral rotation $\left(0^{\circ}\right)$. A two-minute rest was permitted between testing at the different speeds. The participants were instructed to push the lever up and pull it down as hard and as fast as possible with flexion undertaken first for concentric actions and were encouraged to give a maximal effort for each action via both visual feedback and strong verbal encouragement. Strip-chart recording was used to note the highest torque generated in each movement. The effect of gravity was corrected, and the maximum peak torque $(\mathrm{PT})$ ratios in newton-meters were then calculated.

In the OA patients, a standard anteroposterior radiograph of the hip and/or knee was graded according to the Kellgren-Lawrence (KL) grading system (range, 1-4). ${ }^{[20]}$ In addition, a radiograph was performed on the most painful joint if there was more than one joint involvement. The disease activity of the RA patients was evaluated using the Disease Activity Score 28 (DAS 28), a test that includes the 28 commonly affected joints. For this study, tender joint count, swollen joint count, erythrocyte sedimentation rate (ESR), and the global assessment score were used. Scores on the DAS 28 of greater than 5.1 implied high disease activity, and scores below 3.2 indicated low disease activity. ${ }^{[21]}$

\section{Statistical analyses}

Statistical analyses were performed with the SPSS version 16.0 for Windows software program (SPSS Inc., Chicago, IL, USA). Descriptive data was presented as mean \pm standard deviation (SD) or minimummaximum (median). The Kolmogorov-Smirnov test was used to analyze normal distribution assumption of the quantitative outcomes, and the Kruskal-Wallis test was utilized to compare the OA, RA, and control groups because the data was not distributed normally. To compare two groups, the Mann-Whitney $U$ test was used. Any correlations were investigated using Spearman's correlation analysis, and multivariate linear regression analysis was performed to analyze the relationship between the PT ratios and age and VAS pain as well as the 6MWD, RAOS subscales, and DAS 28. Furthermore, univariate analysis of variance (ANOVA) was used to assess the effects of the radiological grade on the 6MWD, RAOS subscales, and PT ratios. The sociodemographic characteristics (education and occupation) of the groups were evaluated with a chi-square test. Before the study commenced, sample size estimation was performed using the PASS 2008 software (NCSS LLC, Kaysville, UT, USA), and we employed data from a previous study ${ }^{[22]}$ in order to have a statistical power of 0.99 and $\alpha=0.05$. We calculated that 40 subjects were required in each group to detect the differences in the VAS pain score. $P$ values of less than 0.05 were considered to be statistically significant.

\section{RESULTS}

The demographic and clinical characteristics of the study sample are shown in Table 1, and no significant difference in the demographics was seen among the three study groups. The mean DAS 28 was $4.32 \pm 0.83$ in the RA patients. Of the OA patients, 22 (52.4\%) had a KL grade of 2 while $20(47.6 \%)$ had a KL grade of 3. The disease duration of the RA patients was significantly longer than for the OA patients $(\mathrm{p}<0.05)$ (Table 1), but there was no significant difference between the OA and RA patients in terms of the VAS pain score $(p>0.05)$ (Table 1). Furthermore, the three groups showed a significant difference with regard to the 6MWD ( $>0.05)$ (Table 1). The ROAS subscales in the $\mathrm{OA}$ and $\mathrm{RA}$ patients differed significantly from the control group $(\mathrm{p}<0.05)$, but there was no statistically significant difference between the two patient groups $(\mathrm{p}>0.05)$ (Table 1). A comparison of the isokinetic torque measurement results of the isokinetic torque meaurements by diagnosis is presented in Table 1. When the PT values of right knee extension at $180 \%$ s were compared with the controls, a statistically significant difference was only found in the OA group $(\mathrm{p}=0.034)$. Otherwise, there were no marked differences between the groups in terms of the isokinetic PT measurements ( $p>0.05)$.

The results of a correlation analysis between the PT values of the knee of the involved limb (or the most painful limb in patients with more than one joint involvement) and the clinical parameters in OA patients are shown in Table 2. The VAS pain 


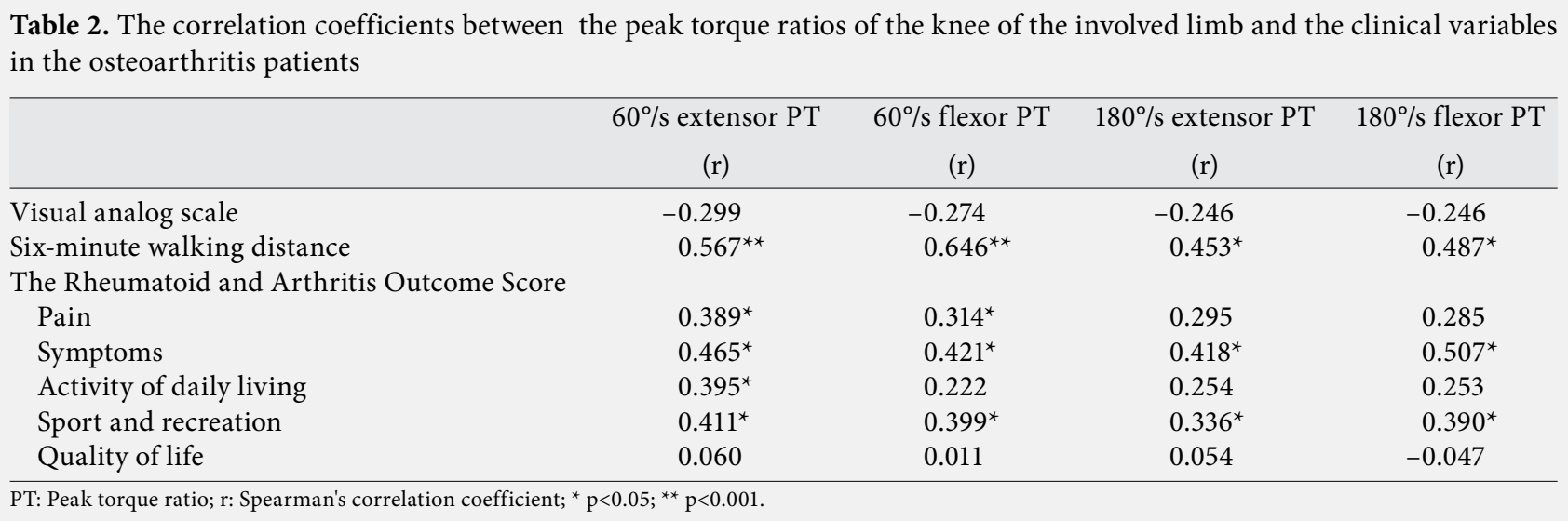

score showed no connection to any of the PT ratios ( $>0.05$ ) (Table 2), but there were positive correlations between the $6 \mathrm{MWD}$ and $\mathrm{PT}$ ratios of knee flexion and extension at $60 \%$ s and at $180 \%$ s (Table 2). Additionally, when a comparison was made between the PT ratios of the knee versus the RAOS subscales in the patients with $\mathrm{OA}$, we found a positive correlation between the PT ratios of knee extension at $60 \% \mathrm{~s}$ and all of the RAOS subscales except for QoL (Table 2). We also found that these ratios was positively correlated with the pain, symptom, and Sport/Rec subscales $(\mathrm{p}<0.05)$ (Table 2) and that the PT ratios of knee flexion and extension at $180 \%$ sere positively correlated with the symptom and Sport/Rec subscales $(\mathrm{p}<0.05)$ (Table 2$)$.

The correlation coefficients between the $\mathrm{PT}$ ratios of the knee of the involved limb (or the most painful limb in patients with more than one joint involvement) and the clinical parameters in RA patients are shown in Table 3. No correlations were identified between the PT ratios of knee extension and flexion at both velocities and the VAS pain score $(\mathrm{p}>0.05)$ (Table 3 ), but the 6MWD was positively correlated with all of the PT ratios of the knee of the affected limb (Table 3). There was also no correlation between the PT ratios of knee extension at $60 \% \mathrm{~s}$ and the RAOS subscales $(p>0.05)$ (Table 3 ), and the same ratios were positively correlated with the symptom, ADL, and QoL subscales $(\mathrm{p}<0.05)$ (Table 3). Furthermore, the PT ratios of knee extension at $180 \%$ s were positively correlated with the pain and ADL subscales while the PT ratios of knee flexion at $180 \%$ were positively correlated with the pain, symptom, and ADL subscales $(\mathrm{p}<0.05)$ (Table 3$)$.

The relationship between the PT ratios and clinical parameters in the OA and RA patients according to multivariate linear regression analysis is shown in Tables 4 and 5 . We found a statistically significant correlation with the PT ratios regarding the 6MWD in both patient groups $(\mathrm{p}<0.05)$ (Tables 4 and 5), but no notable correlations were seen between the PT ratios, and age and VAS pain ( $\mathrm{p}>0.05)$ (Tables 4 and 5). In the OA patients, only the Sport/Rec subscale was associated with the PT ratios of the knee extension

Table 3. The correlation coefficients between the peak torque ratios of the knee of the involved limb and the clinical variables in the rheumatoid arthritis patients

\begin{tabular}{|c|c|c|c|c|}
\hline & $\begin{array}{c}60 \% \text { s extensor } \mathrm{PT} \\
(\mathrm{r})\end{array}$ & $\begin{array}{c}60^{\circ} / \mathrm{s} \text { flexor PT } \\
(\mathrm{r})\end{array}$ & $\begin{array}{c}180 \% \text { s extensor PT } \\
(\mathrm{r})\end{array}$ & $\begin{array}{c}180^{\circ} \text { s flexor PT } \\
\text { (r) }\end{array}$ \\
\hline Visual analog scale & -0.002 & -0.127 & -0.155 & -0.276 \\
\hline Six-minute walking distance & $0.424^{*}$ & $0.401^{*}$ & $0.528^{\star *}$ & $0.530^{\star *}$ \\
\hline \multicolumn{5}{|c|}{ The Rheumatoid and Arthritis Outcome Score } \\
\hline Pain & 0.216 & 0.292 & 306 & $0.381^{\star}$ \\
\hline Symptoms & 0.179 & $0.343^{*}$ & 0.241 & $0.366^{*}$ \\
\hline Activity of daily living & 0.275 & $0.358^{*}$ & $0.377^{\star}$ & $0.396^{*}$ \\
\hline Sport and recreation & 0.216 & 0.273 & 0.278 & 0.214 \\
\hline Quality of life & 0.275 & $0.373^{*}$ & 0.273 & -0.265 \\
\hline Disease Activity Score 28 & -0.129 & -0.082 & -0.069 & -0.148 \\
\hline
\end{tabular}




\begin{tabular}{|c|c|c|c|c|c|c|c|c|c|c|c|c|}
\hline & \multicolumn{3}{|c|}{$60 \%$ s extensor PT } & \multicolumn{3}{|c|}{$60^{\circ} / \mathrm{s}$ flexor $\mathrm{PT}$} & \multicolumn{3}{|c|}{$180 \%$ s extensor PT } & \multicolumn{3}{|c|}{$180^{\circ} / \mathrm{s}$ flexor PT } \\
\hline & $\beta$ & $\mathrm{t}$ & $p$ & $\beta$ & $\mathrm{t}$ & $p$ & $\beta$ & $\mathrm{t}$ & $p$ & $\beta$ & $\mathrm{t}$ & $p$ \\
\hline Age & 0.041 & 0.293 & 0.771 & 0.048 & 0.354 & 0.726 & 0.195 & 1.329 & 0.193 & 0.245 & 1.906 & 0.065 \\
\hline Visual analog scale & -0.174 & -1.073 & 0.149 & -0.182 & -1.155 & 0.257 & -0.123 & -0.766 & 0.449 & -0.171 & -1.213 & 0.234 \\
\hline 6MWD & 0.331 & 2.097 & $0.044^{*}$ & 0.315 & 2.066 & $0.047^{\star}$ & 0.355 & 2.234 & $0.032^{*}$ & 0.420 & 3.136 & $0.004^{*}$ \\
\hline \multicolumn{13}{|l|}{ RAOS } \\
\hline Pain & 0.131 & 0.436 & 0.666 & -0.005 & 0.016 & 0.988 & 0.188 & 0.583 & 0.564 & 0.171 & 0.603 & 0.550 \\
\hline Symptoms & 0.053 & 0.317 & 0.753 & 0.066 & 0.408 & 0.686 & 0.087 & 0.520 & 0.606 & 0.312 & 2.126 & $0.041^{*}$ \\
\hline ADL & -0.273 & -1.231 & 0.227 & -0.384 & -1.782 & 0.084 & -0.237 & 0.998 & 0.325 & -0.393 & -1.887 & 0.068 \\
\hline Sport/Rec & 0.515 & 2.641 & $0.013^{\star}$ & 0.532 & 2.810 & $0.008^{\star}$ & 0.570 & 2.747 & $0.010^{*}$ & 0.501 & 2.754 & $0.009^{*}$ \\
\hline QoL & -0.319 & -1.837 & 0.076 & -0.229 & -1.360 & 0.183 & -0.230 & -1.243 & 0.223 & -0.308 & -1.905 & 0.066 \\
\hline
\end{tabular}

and flexion at $60 \%$ and knee extension at $180 \% \mathrm{~s}$ $(\mathrm{p}<0.05)$ (Table 4). The PT ratios of knee flexion at $180 \%$ were also associated with the symptom and Sport/Rec subscales in this patient group $(\mathrm{p}<0.05)$ (Table 4). In the RA patients, no statistically significant correlations were found between the PT ratios, and the RAOS subscales and DAS 28 ( $>0.05)$ (Table 5). Lastly, no significant effects of the radiological grade were seen with regard to the $6 \mathrm{MWD}$, RAOS subscales, and $\mathrm{PT}$ ratios when they were evaluated by univariate ANOVA ( $>0.05)$.

\section{DISCUSSION}

Musculoskeletal disorders cause much of the severe long-term pain and disability encountered by patients, and $\mathrm{OA}$ and RA are the most common forms of musculoskeletal problems. ${ }^{[4,23]}$ Weight-bearing joints at the lower extremities, mainly the knees and hips, are frequently affected in patients with OA. ${ }^{[1]}$ The involvement of the knee is also usual in RA. ${ }^{[24]}$ In fact, Ringen et al. ${ }^{[25]}$ suggested that lower limb function needs to be considered in the treatment of patients with RA. Furthermore, quadriceps strength, which is usually measured, has been found to be reduced in $\mathrm{OA}$ and RA patients. ${ }^{[9,26]}$ Although the relationship between reduced muscle strength and disability in $\mathrm{OA}$ and RA has been well established, ${ }^{[9,27]}$ comparative research in patients with OA and RA is surprisingly limited in the literature.

Muscle strength is defined as the ability of a muscle or muscle group to exert maximal force or torque at a specific velocity during a contraction, and the isokinetic test objectively determines the measurements related to human muscle strength in the tested position. ${ }^{[24,28]}$ In the current trial, the PT ratios of bilateral knee flexion and extension at $60 \% \mathrm{~s}$

Table 5. Multiple regression analysis with the peak torque ratios of the involved limb as dependent variables and the clinical parameters as independent variables in rheumatoid arthritis patients

\begin{tabular}{|c|c|c|c|c|c|c|c|c|c|c|c|c|}
\hline & \multicolumn{3}{|c|}{$60 \%$ sxtensor PT } & \multicolumn{3}{|c|}{$60 \%$ s Flexor PT } & \multicolumn{3}{|c|}{$180^{\circ} /$ s Extensor PT } & \multicolumn{3}{|c|}{$180^{\circ} / \mathrm{s}$ Flexor PT } \\
\hline & $\beta$ & $\mathrm{t}$ & $p$ & $\beta$ & $\mathrm{t}$ & $p$ & $\beta$ & $\mathrm{t}$ & $p$ & $\beta$ & $\mathrm{t}$ & $p$ \\
\hline Age & 0.094 & 0.530 & 0.599 & 0.059 & 0.351 & 0.728 & 0.086 & 0.488 & 0.629 & -0.110 & -0.714 & 0.480 \\
\hline Visual analog scale & 0.022 & 0.109 & 0.914 & 0.130 & 0.663 & 0.512 & -0.086 & -0.418 & 0.679 & -0.155 & -0.867 & 0.392 \\
\hline 6MWD & 0.460 & 2.282 & $0.029^{*}$ & 0.383 & 1.998 & $0.045^{\star}$ & 0.526 & 2.613 & $0.013^{*}$ & 0.573 & 3.275 & $0.002^{\star}$ \\
\hline \multicolumn{13}{|l|}{ RAOS } \\
\hline Pain & 0.77 & -0.197 & 0.845 & -0.047 & -0.127 & 0.900 & 0.299 & 0.762 & 0.451 & 0.633 & 1.854 & 0.073 \\
\hline Symptoms & -0.020 & -0.075 & 0.940 & 0.148 & 0.597 & 0.554 & -0.015 & -0.059 & 0.953 & 0.004 & 0.017 & 0.987 \\
\hline ADL & 0.119 & 0.281 & 0.780 & 0.194 & 0.484 & 0.632 & -0.317 & -0.752 & 0.458 & -0.296 & -0.807 & 0.425 \\
\hline Sport/Rec & -0.006 & -0.018 & 0.985 & -0.208 & -0.708 & 0.484 & 0.266 & 0.863 & 0.394 & 0.099 & 0.367 & 0.716 \\
\hline QoL & 0.076 & 0.243 & 0.809 & 0.203 & 0.684 & 0.498 & -0.209 & -0.670 & 0.508 & -0.377 & -1.392 & 0.173 \\
\hline
\end{tabular}

PT: Peak torque ratio; 6MWD: Six-minute walking distance; RAOS: The Rheumatoid and Arthritis Outcome Score; ADL: Activity of daily living; Sport/Rec: Sport and recreation; QoL: Quality of life; DAS 28: Disease Activity Score 28 ; ${ }^{*} \mathrm{p}<0.05$. 
and $180 \%$ sere similar in patients with lower limb $\mathrm{OA}$ and RA. In contrast to other studies, ${ }^{[8,9,24,26-28]}$ the muscle strength measurements of the patients in our study did not vary from the controls. As has been previously shown, ${ }^{[30,31]} \mathrm{OA}$ and RA have a negative impact on physical performance. In the current trial, functional performance, as measured by the 6MWD, was also similar in each of these groups. It is well known that muscle strength declines and difficulty in walking increases during the aging process. ${ }^{[28,32]}$ Since our study population was made up of middle-aged OA and RA patients and OA patients with KL scores of between 2 and 3 , the unexpected results should come as no surprise.

In most studies, the physical function of patients with $\mathrm{OA}$ and RA has been assessed by different measures, including the Modified Health Assessment Questionnaire (MHAQ), the Arthritis Impact Measurement Scales (AIMS), and the Western Ontario McMaster Osteoarthritis Index (WOMAC). ${ }^{[4,11,25,33,34]}$ In the current study, lower limb function was assessed by the RAOS, which evaluates symptoms and functional limitations of people with chronic inflammatory joint diseases and problems, especially those involving the lower extremities. Our $\mathrm{OA}$ and RA patients reported more lower extremity dysfunction than the controls, but the RAOS scores of both patient groups were similar.

Although it has been suggested that impairments in muscle strength and power can lead to functional limitations, ${ }^{[28]}$ the self-reported lower limb functions of the two patient groups in this study were worse than in the control group, but the performancebased evaluations (muscle strength and walking time) of the OA, RA, and control groups were similar. In addition, correlation and regression analyses revealed a relationship between muscle strength measurements in the groups, but only a few of the subscales showed any correlation. Thus, the patient's perspective of functional limitation due to lower extremity problems may not be related to the objective functional capacity measurements in patients with lower limb OA and RA.

The results of previous studies showed that OA patients have similar or more pain compared with RA patients; ${ }^{[4,11,33,34]}$ however, in this study, the OA and RA patients reported similar pain severity. In studies that have explored the relationship between muscle strength and pain in OA or RA patients, varied results have been reported. It is well known that loss of muscle strength is an important determinant of pain and disability in patients with $\mathrm{OA},{ }^{[27]}$ and Madsen and Egsmose ${ }^{[9]}$ reported a correlation between muscle strength and pain in RA patients. Furthermore, a study by Ekdahl and Broman ${ }^{[8]}$ showed a significant correlation between pain and muscle strength, but only in women with RA. In contrast, other studies have detected no relationship between isokinetic muscle strength and pain intensity in RA patients. ${ }^{[24,35]}$ In the current trial, no relationship was found between the PT ratios of the knee muscles and the VAS pain scores in the OA and RA patients. Since these patients did not have reduced muscle strength compared with the controls, it might not be possible to detect the relationship between muscle strength and pain severity from our findings.

Controversy exists regarding RA patients as to whether there is an association between muscle strength and disease activity. In a study by Stucki et al., ${ }^{[36]}$ a significant negative correlation was shown between disease activity and isometric muscle strength, whereas Mengshoel et al. ${ }^{[35]}$ reported no correlation. Our study determined that there was no correlation between disease activity and isokinetic muscle strength in patients with lower limb RA. This can be explained by the moderate disease activity scores and undiminished knee muscle strength of the RA patients.

The relationship between muscle strength and radiological changes has been studied extensively, especially in cases of knee OA, but contradictory results have been reported. Some studies showed that quadriceps strength was significantly reduced in patients with radiographic knee OA. ${ }^{[37]}$ However, Brandt et al. ${ }^{[38]}$ detected reduced muscle strength in patients without radiographic knee OA, and PalmieriSmith et al. ${ }^{[39]}$ could not identify any distinction in the quadriceps strength of patients with different radiographic grades according to the KL grading system. In our study, radiological grade was not an influential variable that affected muscle strength in the lower limbs of the OA patients. The reason for this lack of a relationship might stem from the fact that the OA patients had KL scores of 2 and 3. Furthermore, the muscle strength of these patients did not vary from the controls.

The major limitation of this study was that the participants who were all middle-aged and, therefore, had similar characteristics. The RA patients had moderate disease activity, and the OA patients had 
mild or moderate radiographic changes. For this reason, our results are not applicable for older patients with OA and RA in the lower limbs who have better or worse disease severity.

Several studies have focused on the overall deterioration in physical function, muscle strength, or QoL in OA or RA patients, but we are not aware of any previous study that has addressed the relationship between muscle strength and functional status in patients with lower limb OA and RA. According to our results, the OA and RA patients with lower extremity involvement had more physical disability when compared with subjects with no rheumatologic disorders, although no objective impairments such as reduced muscle strength and increased walking time were detected. Additionally, in the patients with lower limb OA and RA, severity of pain and level of physical function were similar despite the differences in the clinical findings and pathophysiology of the two forms of arthritis. Therefore, we conclude that in lower-limb $\mathrm{OA}$ and RA, the burden of disease may be similar, and this can have a negative impact on a patient's functional capacity. Additionally, patient complaints along with objective measurements should be taken into consideration when evaluating patients for the presence of lower limb OA or RA.

\section{Declaration of conflicting interests}

The authors declared no conflicts of interest with respect to the authorship and/or publication of this article.

\section{Funding}

The authors received no financial support for the research and/or authorship of this article.

\section{REFERENCES}

1. Altman RD, Lozada CJ. Clinical features of osteoarthritis. In: Hochberg MC, Silman AJ, Smolen JS, Weinblatt ME, Weisman MH, editors. Rheumatology. 4th ed. Edinburgh: Elsevier Limited; 2008. p. 1703-10.

2. Guidelines for the management of rheumatoid arthritis. American College of Rheumatology Ad Hoc Committee on Clinical Guidelines. Arthritis Rheum 1996;39:713-22.

3. Guccione AA. Arthritis and the process of disablement. Phys Ther 1994;74:408-14.

4. Williams SB, Brand CA, Hill KD, Hunt SB, Moran $\mathrm{H}$. Feasibility and outcomes of a home-based exercise program on improving balance and gait stability in women with lower-limb osteoarthritis or rheumatoid arthritis: a pilot study. Arch Phys Med Rehabil 2010;91:106-14.
5. Osaki M, Tomita M, Abe Y, Ye Z, Honda S, Yoshida S, et al. Physical performance and knee osteoarthritis among community-dwelling women in Japan: the Hizen-Oshima Study, cross-sectional study. Rheumatol Int 2012;32:22459. doi: 10.1007/s00296-011-1949-0.

6. Kettunen JA, Kujala UM. Exercise therapy for people with rheumatoid arthritis and osteoarthritis. Scand J Med Sci Sports 2004;14:138-42.

7. Brill PA, Macera CA, Davis DR, Blair SN, Gordon N. Muscular strength and physical function. Med Sci Sports Exerc 2000;32:412-6.

8. Ekdahl C, Broman G. Muscle strength, endurance, and aerobic capacity in rheumatoid arthritis: a comparative study with healthy subjects. Ann Rheum Dis 1992;51:35-40.

9. Madsen OR, Egsmose C. Associations of isokinetic knee extensor and flexor strength with steroid use and walking ability in women with rheumatoid arthritis. Clin Rheumatol 2001;20:207-12.

10. Beenakker KG, Ling CH, Meskers CG, de Craen AJ, Stijnen T, Westendorp RG, et al. Patterns of muscle strength loss with age in the general population and patients with a chronic inflammatory state. Ageing Res Rev 2010;9:431-6. doi: 10.1016/j.arr.2010.05.005.

11. Slatkowsky-Christensen B, Mowinckel P, Kvien TK. Health status and perception of pain: a comparative study between female patients with hand osteoarthritis and rheumatoid arthritis. Scand J Rheumatol 2009;38:342-8. doi: 10.1080/03009740902913496.

12. Novaes GS, Perez MO, Beraldo MB, Pinto CR, Gianini RJ. Correlation of fatigue with pain and disability in rheumatoid arthritis and osteoarthritis, respectively. Rev Bras Reumatol 2011;51:451-5.

13. Arnett FC, Edworthy SM, Bloch DA, McShane DJ, Fries JF, Cooper NS, et al. The American Rheumatism Association 1987 revised criteria for the classification of rheumatoid arthritis. Arthritis Rheum 1988;31:315-24.

14. Altman R, Asch E, Bloch D, Bole G, Borenstein D, Brandt $\mathrm{K}$, et al. Development of criteria for the classification and reporting of osteoarthritis. Classification of osteoarthritis of the knee. Diagnostic and Therapeutic Criteria Committee of the American Rheumatism Association. Arthritis Rheum 1986;29:1039-49.

15. Altman R, Alarcón G, Appelrouth D, Bloch D, Borenstein $\mathrm{D}$, Brandt $\mathrm{K}$, et al. The American College of Rheumatology criteria for the classification and reporting of osteoarthritis of the hip. Arthritis Rheum 1991;34:505-14.

16. Rejeski WJ, Ettinger WH Jr, Schumaker S, James P, Burns R, Elam JT. Assessing performance-related disability in patients with knee osteoarthritis. Osteoarthritis Cartilage 1995;3:157-67.

17. Bremander AB, Petersson IF, Roos EM. Validation of the Rheumatoid and Arthritis Outcome Score (RAOS) for the lower extremity. Health Qual Life Outcomes 2003;1:55.

18. Karatepe AG, Günaydin R, Türkmen G, Kaya T, Ozbek G. The validity and reliability of the Turkish version of the Rheumatoid and Arthritis Outcome Score (RAOS) in patients with rheumatoid arthritis. Clin Rheumatol 2009;28:47-51. 
19. Maquet D, Croisier JL, Renard C, Crielaard JM. Muscle performance in patients with fibromyalgia. Joint Bone Spine 2002;69:293-9.

20. Kellgren JH, Lawrence JS. Radiological assessment of osteo-arthrosis. Ann Rheum Dis 1957;16:494-502.

21. Leeb BF, Andel I, Sautner J, Bogdan M, Maktari A, Nothnagl $T$, et al. Disease activity measurement of rheumatoid arthritis: Comparison of the simplified disease activity index (SDAI) and the disease activity score including 28 joints (DAS28) in daily routine. Arthritis Rheum 2005;53:56-60.

22. Borman P, Toy GG, Babaoğlu S, Bodur H, Ciliz D, Alli N. A comparative evaluation of quality of life and life satisfaction in patients with psoriatic and rheumatoid arthritis. Clin Rheumatol 2007;26:330-4.

23. Laas $K$, Roine R, Räsänen $P$, Sintonen $H$, Leirisalo-Repo M; HUS QoL Study Group. Health-related quality of life in patients with common rheumatic diseases referred to a university clinic. Rheumatol Int 2009;29:267-73. doi: 10.1007/s00296-008-0673-x.

24. Meireles SM, Oliveira LM, Andrade MS, Silva AC, Natour J. Isokinetic evaluation of the knee in patients with rheumatoid arthritis. Joint Bone Spine 2002;69:566-73.

25. Ringen $\mathrm{HO}$, Dagfinrud $\mathrm{H}$, Mowinckel $\mathrm{P}$, Kvien $\mathrm{T}$. Patients with rheumatoid arthritis report greater physical functional deterioration in lower limbs compared to upper limbs over 10 years. Scand J Rheumatol 2008;37:255-9. doi: 10.1080/03009740801932464.

26. Costa RA, Oliveira LM, Watanabe SH, Jones A, Natour J. Isokinetic assessment of the hip muscles in patients with osteoarthritis of the knee. Clinics (Sao Paulo) 2010;65:1253-9.

27. Steultjens MP, Dekker J, van Baar ME, Oostendorp RA, Bijlsma JW. Muscle strength, pain and disability in patients with osteoarthritis. Clin Rehabil 2001;15:331-41.

28. Puthoff ML, Nielsen DH. Relationships among impairments in lower-extremity strength and power, functional limitations, and disability in older adults. Phys Ther 2007;87:1334-47.

29. Pua YH, Liang Z, Ong PH, Bryant AL, Lo NN, Clark RA. Associations of knee extensor strength and standing balance with physical function in knee osteoarthritis. Arthritis Care Res (Hoboken) 2011;63:1706-14. doi: 10.1002/acr.20615.
30. Grondal L, Tengstrand B, Nordmark B, Wretenberg P, Stark A. The foot: still the most important reason for walking incapacity in rheumatoid arthritis: distribution of symptomatic joints in 1,000 RA patients. Acta Orthop 2008;79:257-61.

31. McDaniel G, Renner JB, Sloane R, Kraus VB. Association of knee and ankle osteoarthritis with physical performance. Osteoarthritis Cartilage 2011;19:634-8.

32. Hollman JH, Kovash FM, Kubik JJ, Linbo RA. Age-related differences in spatiotemporal markers of gait stability during dual task walking. Gait Posture 2007;26:113-9.

33. Slatkowsky-Christensen B, Mowinckel P, Loge JH, Kvien TK. Health-related quality of life in women with symptomatic hand osteoarthritis: a comparison with rheumatoid arthritis patients, healthy controls, and normative data. Arthritis Rheum 2007;57:1404-9.

34. Stebbings S, Herbison P, Doyle TC, Treharne GJ, Highton J. A comparison of fatigue correlates in rheumatoid arthritis and osteoarthritis: disparity in associations with disability, anxiety and sleep disturbance. Rheumatology (Oxford) 2010;49:361-7.

35. Mengshoel AM, Jokstad K, Bjerkhoel F. Associations between walking time, quadriceps muscle strength and cardiovascular capacity in patients with rheumatoid arthritis and ankylosing spondylitis. Clin Rheumatol 2004;23:299-305.

36. Stucki G, Brühlmann P, Stucki S, Michel BA. Isometric muscle strength is an indicator of self-reported physical functional disability in patients with rheumatoid arthritis. Br J Rheumatol 1998;37:643-8.

37. Sattler M, Dannhauer T, Hudelmaier M, Wirth W, Sänger AM, Kwoh CK, et al. Side differences of thigh muscle cross-sectional areas and maximal isometric muscle force in bilateral knees with the same radiographic disease stage, but unilateral frequent pain - data from the osteoarthritis initiative. Osteoarthritis Cartilage 2012;20:532-40.

38. Brandt KD, Heilman DK, Slemenda C, Katz BP, Mazzuca S, Braunstein EM, et al. A comparison of lower extremity muscle strength, obesity, and depression scores in elderly subjects with knee pain with and without radiographic evidence of knee osteoarthritis. J Rheumatol 2000;27:1937-46.

39. Palmieri-Smith RM, Thomas AC, Karvonen-Gutierrez C, Sowers MF. Isometric quadriceps strength in women with mild, moderate, and severe knee osteoarthritis. Am J Phys Med Rehabil 2010;89:541-8. 